Article

\title{
Synthesis, Crystal Structures, and Magnetic Properties of Lanthanide (III) Amino-Phosphonate Complexes
}

\author{
Karzan H. Zangana ${ }^{1,2}$ \\ 1 School of Chemistry, The University of Manchester, Oxford Road, Manchester M13 9PL, UK; \\ karzan.zangana@manchester.ac.uk \\ 2 Department of Chemistry, College of Education, Salahaddin University-Erbil, 44002 Kurdistan Region, Iraq; \\ karzan.shakwr@su.edu.krd or karzan111@yahoo.com; Tel.: +964-66-223-0335
}

Received: 28 May 2018; Accepted: 19 June 2018; Published: 22 June 2018

\begin{abstract}
Two isostructural lanthanide amino-phosphonate complexes $\left[\mathrm{Ln}_{10}\left(\mu_{3}-\mathrm{OH}\right)_{3}(\mu-\mathrm{OH})\left(\mathrm{CO}_{3}\right)_{2}\right.$ $\left.\left(\mathrm{O}_{2} \mathrm{C}^{t} \mathrm{Bu}\right)_{15}\left(\mathrm{O}_{3} \mathrm{PC}_{6} \mathrm{H}_{10} \mathrm{NH}_{2}\right)_{3}\left(\mathrm{O}_{3} \mathrm{PC}_{6} \mathrm{H}_{10} \mathrm{NH}_{3}\right)_{2}\left(\mathrm{H}_{2} \mathrm{O}\right)_{2}\right]\left[\mathrm{Et}_{2} \mathrm{NH}_{2}\right](\mathrm{Ln}=\mathrm{Gd}(\mathrm{III}), \mathbf{1}$ and $\mathrm{Tb}(\mathrm{III}), 2)$ have been obtained through reflux reactions of lanthanide pivalates with, a functionalized phosphonate, (1-amino-1-cyclohexyl)phosphonic acid and diethylamine $\left(\mathrm{Et}_{2} \mathrm{NH}\right)$ in acetonitrile $(\mathrm{MeCN})$ at $90^{\circ} \mathrm{C}$. Both compounds have been characterized with elemental analysis, single-crystal X-ray diffraction methods, and magnetic measurements. The molecular structure of compounds $\mathbf{1}$ and $\mathbf{2}$ reveal two highly unsymmetrical complexes comprising ten lanthanide metal centers, where the lanthanide metal ion centers in the cages are linked through pivalate units and further interconnected by $\mathrm{CPO}_{3}$ tetrahedra to build the crystal structure. The magnetic behavior of $\mathbf{1}$ and $\mathbf{2}$ was investigated between ambient temperature and ca. $2 \mathrm{~K}$, the magnetic measurements for compound 1 suggests antiferromagnetic interactions between the $\mathrm{Gd}(\mathrm{III})$ metal ion centers at low temperatures. The large number of isotropic Gd(III) ions comprising 1 makes it a candidate for magnetocaloric applications, thus the magnetocaloric properties of this molecular cage were investigated indirectly through isothermal magnetisation curves. The magnetic entropy change was found to be $34.5 \mathrm{~J} \mathrm{~kg}^{-1} \mathrm{~K}^{-1}$, making 1 a plausible candidate in magnetic cooling applications.
\end{abstract}

Keywords: lanthanides; amino-phosphonates; crystallography; magnetic studies

\section{Introduction}

In recent years, research involving metal phosphonates has been deeply explored because of the great variety of building blocks available for the preparation of functional materials useful in the field of structural chemistry and magnetic properties [1-7]. Phosphonic acid and its derivatives are flexible coordination ligands towards a wide range of metal ions, with various ionic radii, including $\mathrm{Ln}(\mathrm{III})$ ions, resulting in some materials with promising magnetic properties [8-11].

4f-phosphonate molecular cages have been studied because of the magnetic anisotropies of the lanthanide ions and the weak coupling between the metal ions can produce interesting properties [12]. When the isotropic $\mathrm{Gd}(\mathrm{III})$ metal ion is present, lanthanide phosphonate clusters display impressive magnetocaloric effects (MCE), which have been suggested for application in magnetic refrigeration [13]. Lanthanide phosphonates with structural diversity and related physical and chemical properties could be obtained by modifying phosphonates with different functional organic groups, such as crown ether [14-18], carboxylate [19-23], pyridyl, amino and hydroxyl [24-32], etc. Much of recent work has so far focused on the exploration of metal phosphonate materials with new structural types, and a large number of metal phosphonates were prepared through designing and synthesizing phosphonic 
acids with different functional organic groups [7,33-37]. More recently, a series of metal phosphonates, using phosphonic acids containing $-\mathrm{NH}_{2}$ sub functional group were also isolated under solvothermal condition [38,39].

So far, only few $4 \mathrm{f}$-aminophosphonate molecular cages have been reported, the incorporation of the amino group into a phosphonate ligand could provide additional coordination sites for the metal ions and influence the packing of the structures through weak interactions such as hydrogen-bond interactions [8-11]. The first lanthanide aminophosphonate, $\mathrm{Lu}\left(\mathrm{HO}_{3} \mathrm{PCH}_{2} \mathrm{CH}_{2} \mathrm{NH}_{3}\right)_{3}\left(\mathrm{ClO}_{4}\right)_{3} \cdot 3 \mathrm{D}_{2} \mathrm{O}$ was reported by Legendziwicz et al. in 1999 [40,41]. Due to 4f-phosphonate low solubility in water and other organic solvents as well as their poor crystallinity, it is still a difficult task to obtain single crystals suitable for X-ray structural analysis $[12,13]$. These problems can be solved by two methods: (1) introducing polar functional groups into the ligand, such as hydroxy, amino, carboxylate, or crown ether [42-45]; and (2) introducing a second ligand such as pivalic acid or oxalic acid [41,42]. The introduction of the second ligand is to improve the crystallization of the products, to mediate the electronic effects between paramagnetic metal centers and to link the metal centers into various structures with dimensionalities extending from zero to three [46-48].

Comparatively, few reports are available on the magnetic properties of lanthanide phosphonates prepared under reflux conditions [49-51], with the aim of exploring new 4f-phosphonates with interesting structures and magnetic properties, Herein, the synthesis, crystal structure, and magnetic stability of two novel lanthanide aminophosphonate complexes, with formula $\left[\operatorname{Ln}_{10}\left(\mu_{3}-\mathrm{OH}\right)_{3}\right.$ $\left.(\mu-\mathrm{OH})\left(\mathrm{CO}_{3}\right)_{2}\left(\mathrm{O}_{2} \mathrm{C}^{t} \mathrm{Bu}\right)_{15}\left(\mathrm{O}_{3} \mathrm{PC}_{6} \mathrm{H}_{10} \mathrm{NH}_{2}\right)_{3}\left(\mathrm{O}_{3} \mathrm{PC}_{6} \mathrm{H}_{10} \mathrm{NH}_{3}\right)_{2}\left(\mathrm{H}_{2} \mathrm{O}\right)_{2}\right]\left[\mathrm{Et}_{2} \mathrm{NH}_{2}\right](\mathrm{Ln}=\mathrm{Gd}(\mathrm{III}), \mathbf{1}$ and $\mathrm{Tb}(\mathrm{III}), 2$ ), is reported (Figure 1 and Figure $\mathrm{S} 1$ )
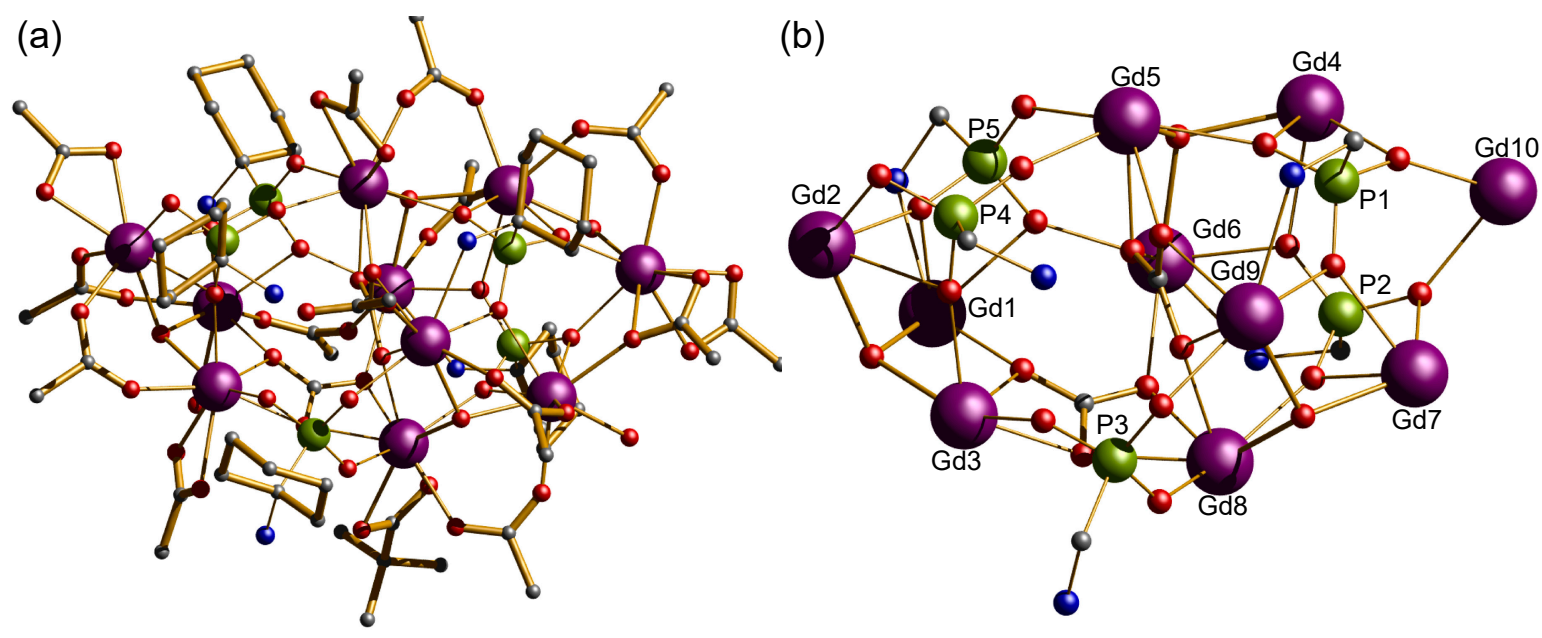

Figure 1. (a) Crystal structure of $\left\{\mathrm{Gd}_{10} \mathrm{P}_{5}\right\}$ cluster. Scheme: $\mathrm{Gd}$, purple; $\mathrm{P}$, green; $\mathrm{O}$, red; $\mathrm{C}$, grey; $\mathrm{N}$, cyan; (H-atoms and Me groups omitted for clarity); (b) metal and phosphonate core in $\left\{\mathrm{Gd}_{10} \mathrm{P}_{5}\right\}$, showing $\mu_{3}-\mathrm{OH}$ centerd metal ions and carbonate moieties.

\section{Results and Discussion}

\subsection{Syntheses of the Complexes}

Phosphonates of general formula $\mathrm{RPO}_{3}$ are well-known as binding groups for molecular metal clusters by using large R groups or co-ligands that inhibit formation of polymeric materials. Previous studies have shown that the phosphonate moiety is an efficient functional group for the construction of molecular cages $[38,39]$. Winpenny and co-workers reported results using $t$-butylphosphonic acid $\left(\mathrm{H}_{2} \mathrm{O}_{3} \mathrm{P}^{t} \mathrm{Bu}\right.$ ) reacted with lanthanide salts $\mathrm{Ln}\left(\mathrm{NO}_{3}\right)_{3} \cdot n \mathrm{H}_{2} \mathrm{O}$ or lanthanide pivalates ( $\mathrm{Ln}=\mathrm{Gd}(\mathrm{III}), \mathrm{Tb}(\mathrm{III})$, $\mathrm{Dy}(\mathrm{III}), \mathrm{Ho}(\mathrm{III})$, and $\mathrm{Er}(\mathrm{III})[12,13,39]$. Winpenny and coworkers have also synthesized a decanuclear 3d-4f phosphonate cage of $\left[\mathrm{Co}_{4} \mathrm{Ln}_{10}\left(\mathrm{O}_{2} \mathrm{C}^{t} \mathrm{Bu}\right)_{12}\left(\mathrm{O}_{3} \mathrm{PC}_{6} \mathrm{H}_{10} \mathrm{NH}_{2}\right)_{8}\left(\mathrm{PO}_{4}\right)_{2}\left(\mathrm{O}_{2} \mathrm{CMe}_{2}\left(\mathrm{O}_{3} \mathrm{PC}_{6} \mathrm{H}_{10} \mathrm{NH}_{3}\right)_{2}\right]\right.$ $(\mathrm{Ln}=\mathrm{Gd}, \mathrm{Dy})[38]$. The molecule crystallizes in a triclinic space group and contains ten lanthanides, 
twelve phosphonates, and four cobalt metal ions. The $\left\{\operatorname{Ln}_{10} \mathrm{P}_{12}\right\}$ core can be described as two centered 12-vertex polyhedra sharing a face, the phosphonates present three different coordination modes of $6.222,4.2111$, and 3.1111. More recently, Winpenny and co-workers also reported two cages of centered nine-metal rings of lanthanides $\left[\mathrm{Co}_{3}\left(\mu_{3}-\mathrm{O}\right)\left(\mathrm{O}_{2} \mathrm{C}^{t} \mathrm{Bu}\right)_{6}(\mathrm{py})_{3}\right]\left[\mathrm{Ln}_{10}\left(\mathrm{O}_{2} \mathrm{C}^{t} \mathrm{Bu}\right)_{18}\left(\mathrm{O}_{3} \mathrm{P}^{t} \mathrm{Bu}\right)_{6}(\mathrm{OH})\left(\mathrm{H}_{2} \mathrm{O}\right)_{4}\right]$ $(\mathrm{Ln}=\mathrm{Dy}, \mathrm{Gd})$. The compounds are isostructural and contain an anionic $\left\{\mathrm{Ln}_{10}\right\}$ cage co-crystallized with a $\left[\mathrm{Co}_{3}\left(\mu_{3}-\mathrm{O}\right)\left(\mathrm{O}_{2} \mathrm{CtBu}\right)_{6}(\mathrm{py})_{3}\right]^{+}$cation, the anion of the compound contains nine $\mathrm{Ln}(\mathrm{III})$ metal ions in a ring and a tenth $\mathrm{Ln}(\mathrm{III})$ metal ion at the center of the structure, the ten metal sites are almost co-planar. Three of the six phosphonates lie below the plane of the $\left\{\mathrm{Ln}_{10}\right\}$ disc and adopt the 4.221 binding mode, the remaining three phosphonates are above the plane of metal centers; two of them adopt the 3.111 binding mode, while the third adopts the 3.211 mode [52]. Another frequently used ligand to the polynuclear $4 \mathrm{f}$ molecular cages is $\alpha$-amino acids [42-45], thus 1-amino-1-cyclohexyl phosphonic acid is supposedly a good ligand to synthesize $4 \mathrm{f}$ molecular cages (Figure 2) [38,39]. Herein the use of an aminophosphonic acid ligand to synthesize two $4 \mathrm{f}$-phosphonate clusters is provided. The reactions have been performed by refluxing a mixture of lanthanide pivalate $\left[\mathrm{Ln}_{2}\left(\mathrm{O}_{2} \mathrm{C}^{t} \mathrm{Bu}\right)_{6}\left(\mathrm{HO}_{2} \mathrm{C}^{t} \mathrm{Bu}\right)_{6}\right]$ $(\mathrm{Ln}=\mathrm{Gd}(\mathrm{III}) ; \mathrm{Tb}(\mathrm{III}))$, (1-amino-1-cyclohexyl) phosphonic acid $\left(\mathrm{H}_{2} \mathrm{O}_{3} \mathrm{PC}_{6} \mathrm{H}_{10} \mathrm{NH}_{2}\right)$, and a mild base, $\mathrm{Et}_{2} \mathrm{NH}$ in $\mathrm{MeCN}$ in the mole ratios 0.1:0.5:0.01.
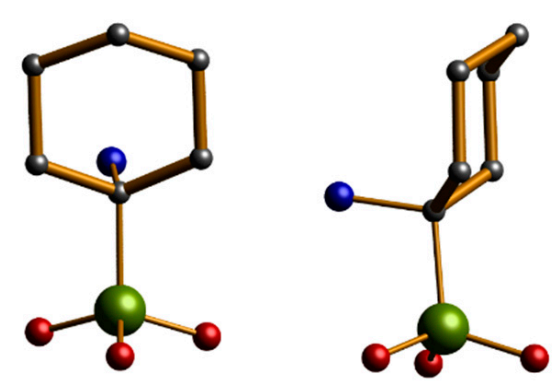

Figure 2. The structure of (1-amino-1-cyclohexyl) phosphonic acid. Scheme: P, green; O, red; C, grey; $\mathrm{N}$, cyan; (H omitted for clarity).

\subsection{Description of the Structures}

Compounds 1 and 2 both crystallize in the monoclinic space group $P 21 / n$ and are isostructural, allowing us to describe compound 1 as representative. The compounds contain an anionic $\left\{\operatorname{Ln}_{10}\right\}$ cage co-crystallized with a $\left[\mathrm{Et}_{2} \mathrm{NH}_{2}\right]^{+}$cation. The metal ions are highly irregular and are best described as a square sandwiched between two triangles (Figure 1, Figures S1 and S2) Compound 1 contains ten lanthanide(III) metal ion centers and the compound is held together by fifteen pivalates, two carbonates, three $\mu_{3}-\mathrm{OH}$, and five (1-amino-1-cyclohexyl) phosphonic acid ligands. P1 and P2 bind to five Gd(III) metal ion centers; adopting a [5.2221] coordination mode (as described using Harris notation [53], see Figure 3), P3 and P4 bind to three Gd(III) metal ion centers; adopting [3.1110] and [3.211] coordination modes, respectively. While, P5 binds to four Gd(III) metal ion centers using the [4.2211] binding mode. The carboxylates adopt three different coordination modes, 2.11, 1.11, and 1.10. There are three $\mu_{3}$-hydroxide centered gadolinium triangles formed by (Gd1, Gd2, Gd3), (Gd4, Gd5, Gd6), and (Gd7, Gd8, Gd9), while the two $\mu_{3}$-hydroxide centered gadolinium triangles that are defined by $(\mathrm{Gd} 4, \mathrm{Gd} 5, \mathrm{Gd} 6)$ and $(\mathrm{Gd} 7, \mathrm{Gd} 8, \mathrm{Gd} 9)$ lie parallel to each other and share two edges (Gd5-Gd6) and (Gd8-Gd9) with the central distorted square. Whereas, Gd10 is in a bridging position between the vertices Gd4 and Gd7. The phosphonate, pivalate, and carbonate oxygen atoms are intensively coordinated to the edges and the vertexes of the three $\mu_{3}-\mathrm{OH}$ centered triangles, for example, six oxygen atoms of the two carbonates bind to three vertexes and three edges of the three $\mu_{3}-\mathrm{OH}$ centered triangles. The carbonates must arise from the atmospheric $\mathrm{CO}_{2}$ fixation [54-57]. Two different geometries are adopted by the Gd(III) ions in the cluster: whilst Gd2, Gd3 Gd5, Gd6, $\mathrm{Gd} 8, \mathrm{Gd} 9$, and Gd10 exhibit a triangular dodecahedron $\left(\mathrm{D}_{2 \mathrm{~d}}\right)$ and a Continuous Shape Measure value (CShM) of 1.750, 2.422, 0.804, 2.505, 0.715, 3.236, and 2.316 respectively; Gd1, Gd4, and Gd7 adopt a 
less regular coordination (muffin, Cs, with a CShM value of 2.776, 1.238 and 1.569) [58]. (Figure S3 and Table S1). The Gd...Gd distance in the edges of the triangles is ca. $3.9 \AA$ and the three $\mu_{3}-\mathrm{OH}$ groups are displaced about $0.81 \AA$ out of the plane of the metal ions. The Gd . . Gd distances within the central distorted square are in the range 4.0749(7)-4.8390(8) $\AA$, whereas the distances between Gd10 metal ion and each of the vertexes Gd4 and Gd7 are in the range 7.0318(9)-6.3986(9) $\AA$, respectively (Table S2). In the crystal, four molecules reside in the unit cell, which are held together through hydrogen bonds between the non-coordinated water molecules residing in the pockets on the crystals and the $\mathrm{NH}_{2}$ groups of the aminophosphonic groups. Likewise, hydrogen bonding is also observed between the nitrogen of the $\mathrm{MeCN}$ solvents molecules and some terminal $\mathrm{H}_{2} \mathrm{O}$ molecules coordinated to the lanthanide ions.
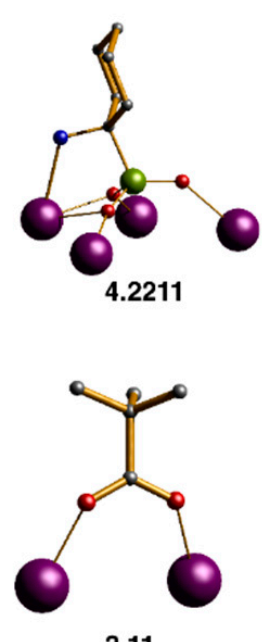
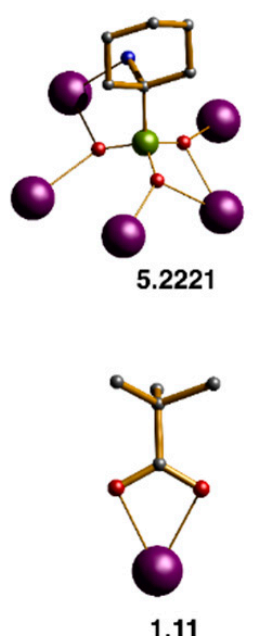
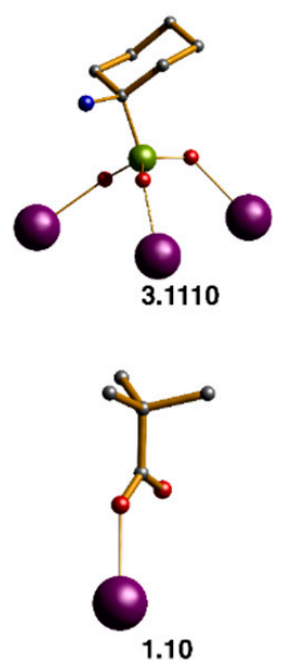

Figure 3. Scheme for binding modes by Harris notation of the phosphonates and acetates in the clusters 1 and 2. Scheme: Ln, purple; P, light green; O, red; C, grey; N, cyan; H omitted for clarity.

\subsection{Magnetic Properties}

The temperature dependence of the magnetic susceptibility of $\mathbf{1}$ and $\mathbf{2}$ were determined by employing a SQUID magnetometer. Microcrystalline samples were suspended in $n$-eicosane and measured under a DC field of $1000 \mathrm{Oe}$ in the temperature range comprising 2-300 K. The temperature dependence of the $\chi_{M} T(T)$ (where $\chi_{M}$ is the molar magnetic susceptibility) for 1 was $78.3 \mathrm{emu} \mathrm{mol}{ }^{-1}$ $\mathrm{K}$ at $300 \mathrm{~K}$ (Figure $4 \mathrm{a}$ ), this value is slightly lower than expected (calcd. $78.7 \mathrm{~cm}^{3} \mathrm{~K} \mathrm{~mol}^{-1}$ for ten $\left.\mathrm{Gd}(\mathrm{III}): g_{J}=2, J=7 / 2\right)$. Upon cooling, the $\chi_{M} T$ remains constant to ca. $75 \mathrm{~K}$ before falling rapidly to $54 \mathrm{~cm}^{3} \mathrm{~K} \mathrm{~mol}^{-1}$ at $2 \mathrm{~K}$ due to the depopulation of the ligand field levels and/or the antiferromagnetic interactions. The high temperature flat region of the $\chi_{M} T$ curve hints very weak magnetic interaction between $\mathrm{Gd}(\mathrm{III})$ metal ion centers. The room temperature $\chi_{M} T$ value for complex 2 (Figure S4) is $118.3 \mathrm{~cm}^{3} \mathrm{~K} \mathrm{~mol}^{-1}$, in agreement with the spin only value (calcd. $118.1 \mathrm{~cm}^{3} \mathrm{~K} \mathrm{~mol}^{-1}$ for ten $\mathrm{Tb}$ (III): $g_{J}=3 / 2 ; J=6$ ). The curve decreases slowly with decreasing temperature down to about $100 \mathrm{~K}$, before decreasing more rapidly. The continuing fall of $\chi_{M} T$ at all temperatures for compound 2 proposes an effect from the combined action of the crystal-field effect of the $\mathrm{Tb}(\mathrm{III})$ and the possibly antiferromagnetic exchange interaction between the metal ion centers. In addition, alternating current magnetic susceptibilities studied were carried out for compound 2 to probe the Single Molecule Magnet character (SMM), revealing no out-of-phase component, thus $\mathbf{2}$ is not an SMM.

Magnetization $(M)$ versus field $(H)$ plots from 2 to $9 \mathrm{~K}$ (Figure $4 \mathrm{~b}$ ) for compound 1 shows a steady increase that reaches $68.3 \mu_{B}$ at $7 \mathrm{~T}$ at $2 \mathrm{~K}$. This value approaches the saturation value for ten paramagnetic $S=7 / 2, g=2 \mathrm{Gd}(\mathrm{III})$ metal ion centers, calculated from the Brillouin function. As observed in Figure $4 \mathrm{~b}$, at low fields the $M(H)$ at $2 \mathrm{~K}$ is significantly lower than the Brillouin function, 
indicating that antiferromagnetic interactions could be operative within the clusters. For $2, M$ vs. $H$ curve increase with increasing field, the plots of 2 and $4 \mathrm{~K}$ show a linear increase after $3 \mathrm{~T}$ that reaches $41.8 \mu_{B}$ at $7 \mathrm{~T}$ at $2 \mathrm{~K}$ without reaching saturation (Figure S5), this is the typical shape of $M$ versus $H$ plot that indicates significant magnetic anisotropy.
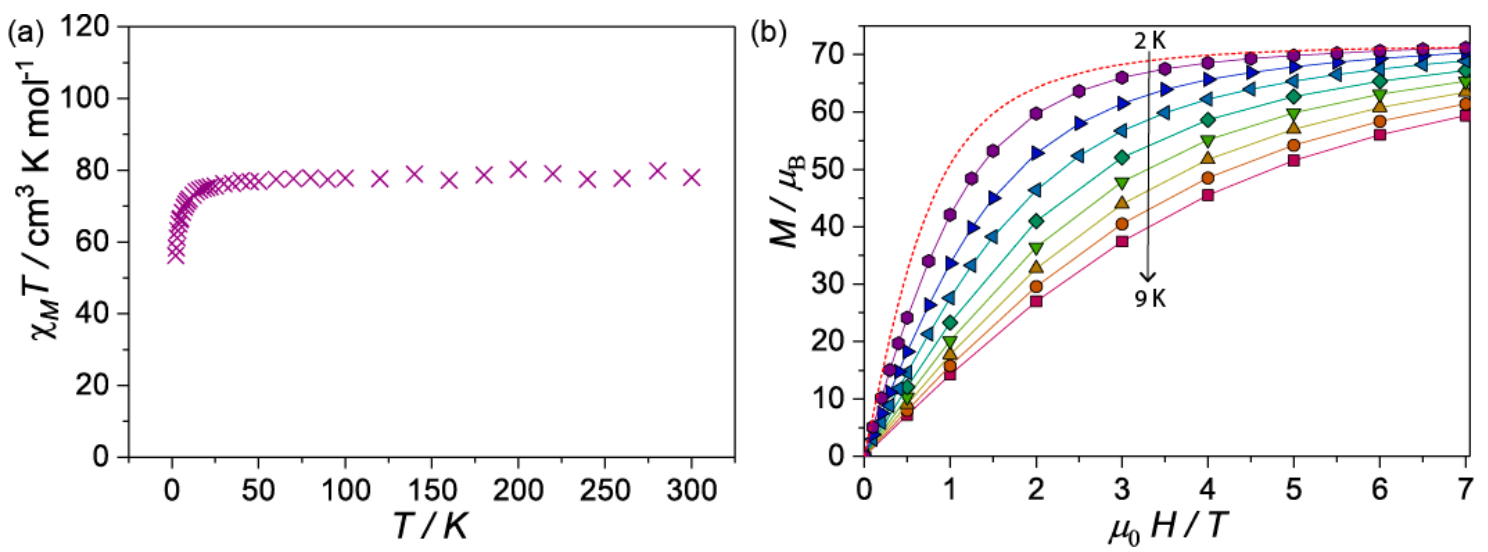

Figure 4. (a) Variation of $\chi_{\mathrm{M}} T$ vs. $T$ for 1 at $1 \mathrm{kOe}$ from 2-300 K; (b) $M_{\beta}$ vs. $H$ for 1 at different temperatures $(2-9 \mathrm{~K})$ in the field range comprising 0 to $7 \mathrm{~T}$. Dotted line is the Brillouin function at $2 \mathrm{~K}$ for ten isolated $\mathrm{Gd}(\mathrm{III})\left(g_{J}=2.00\right.$ and $\left.S=7 / 2\right)$.

Studies of the entropy changes from the magnetization data suggest the gadolinium-containing compounds could be suitable for low-temperature magnetic cooling (MCE), In this context, the high magnetization value obtained for compound $\mathbf{1}$ and the magnetic entropy change was studied to examine whether compound 1 could be used for magnetic cooling applications. The MCE can be described as $\Delta S=\int[\partial M(T, H) / \partial T]_{H} \mathrm{~d} H$ [49-51]. The calculated plot (Figure 5) gives peak value for a field change $\Delta H=70 \mathrm{kG}$ of $3 \mathrm{~K}$ of $34.5 \mathrm{~J} \mathrm{~kg}^{-1} \mathrm{~K}^{-1}$. The maximum entropy value per mole given by $n \mathrm{R} \ln (2 \mathrm{~S}+1)[n=10 \mathrm{Gd}(\mathrm{III})$ spins $s=7 / 2]$, corresponding to the sum of the individual contributions from the $\mathrm{Gd}(\mathrm{III})$ metal ion spins, is $47.9 \mathrm{~J} \mathrm{~kg}^{-1} \mathrm{~K}^{-1}$. These values are not reached experimentally mainly because of the antiferromagnetic interactions between the metal centers in compound $\mathbf{1}$, which are known to decrease the magnetic entropy.

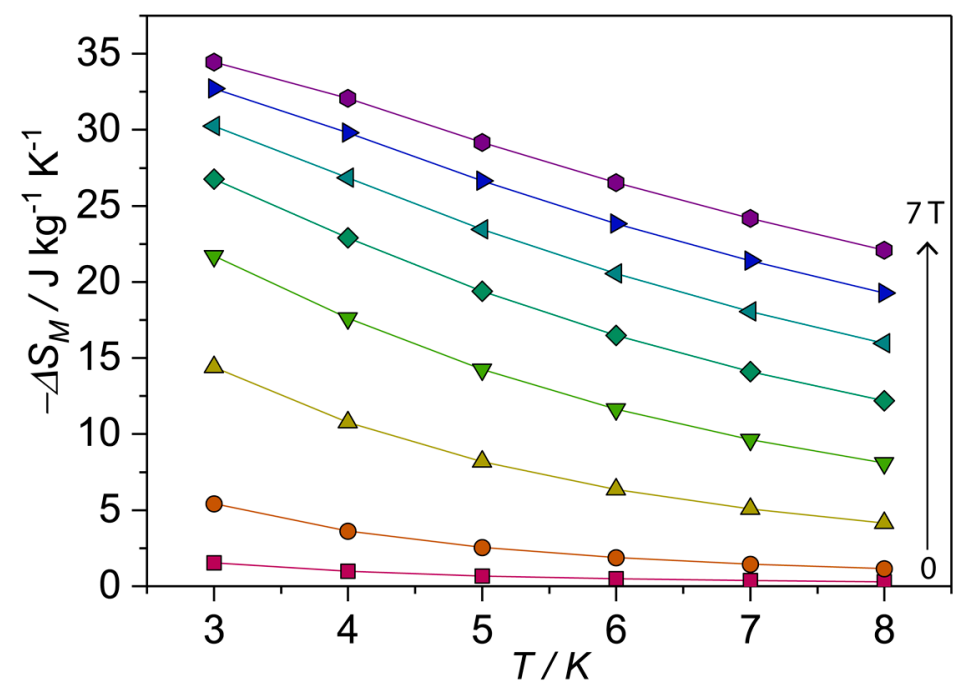

Figure 5. Magnetic entropy changes for compound 1 calculated from isothermal magnetization measurements. 


\section{Experimental Section}

\subsection{Starting Materials}

Unless stated otherwise, all reagents and solvents were purchased from Aldrich Chemicals and used without further purification. (1-amino-1-cyclohexyl) phosphonic acid synthesized according to the reported method [59]. [ $\left.\mathrm{Ln}_{2}\left(\mathrm{O}_{2} \mathrm{C}^{t} \mathrm{Bu}\right)_{6}\left(\mathrm{HO}_{2} \mathrm{C}^{t} \mathrm{Bu}\right)_{6}\right](\mathrm{Ln}=\mathrm{Gd}(\mathrm{III})$; $\mathrm{Tb}(\mathrm{III})$ ) were synthesized following the reported procedure $[60,61]$. Analytical data were obtained by the microanalytical service of the University of Manchester. The data and yields are given in Table 1.

\subsection{Synthesis of $\left[\mathrm{Ln}_{10}\left(\mu_{3}-\mathrm{OH}\right)_{3}(\mu-\mathrm{OH})\left(\mathrm{CO}_{3}\right)_{2}\left(\mathrm{O}_{2} \mathrm{C}^{t} \mathrm{Bu}\right)_{15}\left(\mathrm{O}_{3} \mathrm{PC}_{6} \mathrm{H}_{10} \mathrm{NH}_{2}\right)_{3}\left(\mathrm{O}_{3} \mathrm{PC}_{6} \mathrm{H}_{10} \mathrm{NH}_{3}\right)_{2}\left(\mathrm{H}_{2} \mathrm{O}\right)_{2}\right]$ $\left[E t_{2} \mathrm{NH}_{2}\right](\mathrm{Ln}=\mathrm{Gd}(\mathrm{III}), 1$ and $\mathrm{Tb}(\mathrm{III}), 2)$}

Compound 1 was synthesized by refluxing a mixture of $\left[\mathrm{Gd}_{2}\left(\mathrm{O}_{2} \mathrm{C}^{t} \mathrm{Bu}\right)_{6}\left(\mathrm{HO}_{2} \mathrm{C}^{t} \mathrm{Bu}\right)_{6}\right](0.15 \mathrm{~g}$, $0.1 \mathrm{mmol}), \mathrm{H}_{2} \mathrm{O}_{3} \mathrm{PC}_{6} \mathrm{H}_{10} \mathrm{NH}_{2}(0.09 \mathrm{~g}, 0.5 \mathrm{mmol})$, distilled water $(0.1 \mathrm{~mL})$ and $\mathrm{Et}_{2} \mathrm{NH}(0.1 \mathrm{~mL})$ in $\mathrm{MeCN}(15 \mathrm{~mL})$ at $90{ }^{\circ} \mathrm{C}$ for $4 \mathrm{~h}$ to form a clear solution. The solution was cooled down to room temperature, filtered and then allowed to stand undisturbed at room temperature for 25 days. Colorless rod-shaped crystals suitable for single crystal X-ray diffraction of $\left[\mathrm{Gd}_{10}\left(\mu_{3}-\mathrm{OH}\right)_{3}\right.$ $\left.(\mu-\mathrm{OH})\left(\mathrm{CO}_{3}\right)_{2}\left(\mathrm{O}_{2} \mathrm{C}^{t} \mathrm{Bu}\right)_{15}\left(\mathrm{O}_{3} \mathrm{PC}_{6} \mathrm{H}_{10} \mathrm{NH}_{2}\right)_{3}\left(\mathrm{O}_{3} \mathrm{PC}_{6} \mathrm{H}_{10} \mathrm{NH}_{3}\right)_{2}\left(\mathrm{H}_{2} \mathrm{O}\right)_{2}\right]\left[\mathrm{Et}_{2} \mathrm{NH}_{2}\right]$, were collected. Similar reaction with $\left[\mathrm{Tb}_{2}\left(\mathrm{O}_{2} \mathrm{C}^{t} \mathrm{Bu}\right)_{6}\left(\mathrm{HO}_{2} \mathrm{C}^{t} \mathrm{Bu}\right)_{6}\right](0.1 \mathrm{mmol})$ gave crystals of $\left[\mathrm{Tb}_{10}\left(\mu_{3}-\mathrm{OH}\right)_{3}(\mu-\mathrm{OH})\right.$ $\left.\left(\mathrm{CO}_{3}\right)_{2}\left(\mathrm{O}_{2} \mathrm{C}^{t} \mathrm{Bu}\right)_{15}\left(\mathrm{O}_{3} \mathrm{PC}_{6} \mathrm{H}_{10} \mathrm{NH}_{2}\right)_{3}\left(\mathrm{O}_{3} \mathrm{PC}_{6} \mathrm{H}_{10} \mathrm{NH}_{3}\right)_{2}\left(\mathrm{H}_{2} \mathrm{O}\right)_{2}\right]\left[\mathrm{Et}_{2} \mathrm{NH}_{2}\right]$, (Table 1). Similar reactions with the salts $\left[\mathrm{Ln}_{2}\left(\mathrm{O}_{2} \mathrm{C}^{t} \mathrm{Bu}\right)_{6}\left(\mathrm{HO}_{2} \mathrm{C}^{t} \mathrm{Bu}\right)_{6}\right](\mathrm{Ln}=\mathrm{Dy}(\mathrm{III}), \mathrm{Ho}(\mathrm{III})$ and $\mathrm{Er}(\mathrm{III}))$ of the rest of lanthanides failed to give crystallize materials. IR of crystalline samples gave identical IR spectra for $\mathbf{1}$ and $\mathbf{2}\left(\mathrm{cm}^{-1}\right)$ : 2964.0, 2923.7, 2985.8, 2961.2, 1706.1, 1609.1, 1479.2, 1411.9, 1371.6, 1207.3, 1162.1, 1071.8, 1026.6, 969.9, 809.2, 811.4, 760.4, 692.2, and 629.7 (Figure S6).

Table 1. Elemental analysis and yield (\%) for compounds $\mathbf{1}$ and $\mathbf{2 .}$

\begin{tabular}{lcccccc}
\hline \multicolumn{2}{c}{ Compound $^{b}$} & \multicolumn{2}{c}{ Yield ${ }^{a}$} & \multicolumn{3}{c}{ Elemental Analysis: Found (Calculated) } \\
\hline & & C & H & Ln & P & N \\
\hline $\mathbf{1}(\mathrm{MeCN})_{5}$ & $45 \%$ & $32.50(32.45)$ & $5.15(5.20)$ & $35.15(35.10)$ & $3.45(3.46)$ & $3.48(3.44)$ \\
\hline $\mathbf{2}(\mathrm{MeCN})_{8}$ & $39 \%$ & $33.06(33.02)$ & $5.21(5.24)$ & $34.38(34.40)$ & $3.38(3.35)$ & $4.22(4.25)$ \\
\hline${ }^{a}$ Calculated based on the lanthanide pivalate starting material; ${ }^{b}$ Both samples were filtered and dried at room \\
temperature before conducting the Elemental Analysis (EA). Despite this, the EA clearly suggests the presence of \\
some solvent molecules in the lattice.
\end{tabular}

\subsection{Magnetic Measurements}

Magnetic measurements were performed in temperature ranges of 2-300 K, using a Quantum Design MPMS-XL7 SQUID magnetometer equipped with a $7 \mathrm{~T}$ magnet. The samples were grounded and placed in a gel capsule. Small amounts of eicosane have been used to avoid movement of the sample during the measurement. The diamagnetic corrections for the compounds were estimated using Pascal's constants, and the magnetic data were corrected for diamagnetic contribution of the sample holder. AC magnetic measurements were conducted for compound 2 employing an oscillating magnetic field of 1.55 Oe and under diverse DC fields.

\subsection{Crystallographic Data Collection and Refinement}

Data collection was carried out on Agilent SUPERNOVA diffractometer using graphite-monochromator MoK $\alpha$ radiation $(\lambda=0.71073 \AA)$. A hemisphere of data was collected using a narrow-frame method with scan widths of $0.30 \mathrm{o}$ in $\omega$ and an exposure time of $10 \mathrm{~s}$ per frame. Data reduction and unit cell refinement were performed with CrysAlisPro software. The structures were solved by direct method using SHELXS-97 [61] and were refined by full-matrix least-squares calculations on F2 using the program Olex2 [62]. Suitable crystals of 1 and 2 were selected under microscope and mounted on a tip using crystallographic oil and placed in a cryostream and used for data collection. All non-hydrogen 
atoms were refined anisotropically, all $\mathrm{H}$ atoms were put in calculated positions using riding model, and were refined isotropically, with the isotropic vibration parameters related to the non- $\mathrm{H}$ atom to which they are bonded. Large solvent accessible voids were found for complexes $\mathbf{1}$ and $\mathbf{2}$, however, the location of discrete solvent molecules could not be determined by simple refinement, and therefore the contents of the large voids on the crystal structure were determined using the solvent masking procedure SQUEEZE using Platon [63]. Table 2 contains the molecular formula for 1 and 2 considering all solvent molecules found; i.e., the ones localized in the lattice and those determined by the SQUEEZE analysis. The crystallographic data for $\mathbf{1}$ and $\mathbf{2}$ are listed in Table 2. Selected bond lengths are given in Table S2. CCDC 1584149-1584150 contain the supplementary crystallographic data for $\mathbf{1}$ and $\mathbf{2}$ for this paper.

Table 2. Crystallographic information for clusters 1 and 2.

\begin{tabular}{ccc}
\hline & $\mathbf{1}$ & $\mathbf{2}$ \\
\hline Formula $^{a}$ & $\mathrm{C}_{134} \mathrm{H}_{249.5} \mathrm{Gd}_{10} \mathrm{~N}_{17.5} \mathrm{O}_{59}$ & $\mathrm{C}_{149} \mathrm{H}_{270} \mathrm{~Tb}_{10} \mathrm{~N}_{25} \mathrm{O}_{59} \mathrm{P}_{5}$ \\
$\mathrm{Fw}$ & $\mathrm{P}_{5}$ & 4463.60 \\
$\mathrm{~T} / \mathrm{K}$ & 4366.81 & $150(1)$ \\
Cryst system & $150(1)$ & monoclinic \\
space group & monoclinic & $P 2_{1} / n$ \\
$\mathrm{a} / \AA$ & $P 2_{1} / n$ & $18.0239(3)$ \\
$\mathrm{b} / \AA$ & $17.9933(3)$ & $34.0856(4)$ \\
$\mathrm{c} / \AA$ & $33.9737(5)$ & $28.6516(4)$ \\
$\alpha /^{\circ}$ & $28.6063(4)$ & 90 \\
$\beta /^{\circ}$ & 90 & $91.006(2)$ \\
$\gamma /^{\circ}$ & $90.883(2)$ & 90 \\
$\mathrm{~V} / \AA^{3}$ & 90 & $17599.6(4)$ \\
$\mathrm{Z}$ & $17484.9(5)$ & 4 \\
$\varrho$ calcd $^{\circ} \mathrm{g} \mathrm{cm}^{-3}$ & 2 & 1.678 \\
$\mu(\mathrm{Mo} \mathrm{K} \alpha) / \mathrm{mm}^{-1}$ & 1.659 & 4.083 \\
$\left.\mathrm{R}_{1}(I>2 \sigma)(I)\right)^{a}$ & 3.855 & 0.0714 \\
$\mathrm{wR}{ }^{a}$ & 0.0516 & 0.1459 \\
\hline
\end{tabular}

${ }^{a}$ Molecular formula based on fully localize MeCN molecules and non-localized molecules determined through the SQUEEZE procedure. ${ }^{a} \mathrm{R} 1=|| \mathrm{F}_{\mathrm{o}}|-| \mathrm{F}_{\mathrm{c}}|| /\left|\mathrm{F}_{\mathrm{o}}\right|, \mathrm{wR}_{2}=\left[\mathrm{w}\left(\left|\mathrm{F}_{\mathrm{o}}\right|-\left|\mathrm{F}_{\mathrm{c}}\right|\right)^{2} / \mathrm{w}\left|\mathrm{F}_{\mathrm{o}}\right|^{2}\right]^{1 / 2}$.

\section{Conclusions}

In summary, two new lanthanide $4 \mathrm{f}$-aminophosphonate with structure $\left[\mathrm{Ln}_{10}\left(\mu_{3}-\mathrm{OH}\right)_{3}\right.$ $\left.(\mu-\mathrm{OH})\left(\mathrm{CO}_{3}\right)_{2}\left(\mathrm{O}_{2} \mathrm{C}^{t} \mathrm{Bu}\right)_{15}\left(\mathrm{O}_{3} \mathrm{PC}_{6} \mathrm{H}_{10} \mathrm{NH}_{2}\right)_{3}\left(\mathrm{O}_{3} \mathrm{PC}_{6} \mathrm{H}_{10} \mathrm{NH}_{3}\right)_{2}\left(\mathrm{H}_{2} \mathrm{O}\right)_{2}\right]\left[\mathrm{Et}_{2} \mathrm{NH}_{2}\right](\mathrm{Ln}=\mathrm{Gd}(\mathrm{III}) ; \mathrm{Tb}(\mathrm{III}))$ have been successfully synthesized by using (1-amino-1-cyclohexyl)phosphonic acid ligand and pivalic acid as the second metal linker under reflux conditions at $90^{\circ} \mathrm{C}$ for $4 \mathrm{~h}$, both compounds are structurally and magnetically characterized. Compounds $\mathbf{1}$ and $\mathbf{2}$ are isostructural crystallizing in a monoclinic unit cell. Three different amino-phosphonate binding modes are found in the compounds. Previous results from our group and others indicate that the alkyl groups attached to the aminophosphonic acid has a strong effect on the structures and properties of the lanthanide(III) phosphonates isolated [38,39]. The aminophosphonic acids, $\mathrm{H}_{2} \mathrm{NRPO}_{3} \mathrm{H}_{2}(\mathrm{R}=$ alkyl or aryl group), have been proved to be very useful ligands for the synthesis of metal phosphonates with new structure types in which the organic part plays a controllable spacer role and the two inorganic- $\mathrm{PO}_{3}$ groups chelate with metal ions to form one-, two-, and three-dimensional structures [64,65]. The entropy value for Gadolinium containing complex is $34.5 \mathrm{~J} \mathrm{~kg}^{-1} \mathrm{~K}^{-1}$, this value being larger than the value of $32.3 \mathrm{~J} \mathrm{~kg}^{-1} \mathrm{~K}^{-1}$ of a previously studied octametallic $4 \mathrm{f}$-phosphonate horseshoes complex $\left\{\mathrm{Gd}_{8} \mathrm{P}_{6}\right\}$ [13] for a field change $\Delta H=7 \mathrm{~T}$ at $3 \mathrm{~K}$. Our future research efforts will be devoted to the syntheses, crystal structures, and magnetic properties of lanthanide(III) compounds of other related amino-phosphonate ligands. 
Supplementary Materials: The following are available online at http://www.mdpi.com/2312-7481/4/3/29/s1. Figure S1: Crystal structure of $\left\{\operatorname{Ln}_{10} \mathrm{P}_{5}\right\}$ cluster, Figure S2: Metal and phosphonate core in $\left\{\mathrm{Gd}_{10} \mathrm{P}_{5}\right\}$, Figure S3: Polyhedral view of $\left\{\mathrm{Ln}_{10} \mathrm{P}_{5}\right\}$ core, Figure S4: Variation of $\chi_{\mathrm{M}} T$ vs. $T$ for 2 at 1 kOe from 2-300 K, Figure S5: $M_{\beta}$ vs. $H$ for 2 at different temperatures $(2-9 \mathrm{~K})$ in the field range comprising 0 to 7 T, Figure S6: IR spectra for compound 1 (blue trace) and compound 2 (green trace), Table S1: CShM values for the Gd metal ion centers of $\mathbf{1}$, Table S2. Selected bond distances and angles of compounds 1 and 2.

Acknowledgments: The author thanks Richard Winpenny, and Eufemio Moreno-Pineda for their assistance and insightful conversations, and The University of Manchester for providing facilities.

Conflicts of Interest: The author declares no conflict of interest.

\section{References}

1. Clearfield, A. Organically Pillared Micro- and Mesoporous Materials. Chem. Mater. 1998, 10, $2801-2810$. [CrossRef]

2. Groves, J.A.; Miller, S.R.; Warrender, S.J.; Mellot, D.-C.; Lightfoot, P.; Wright, P.A. The first route to large pore metal phosphonates. Chem. Commun. 2006, 31, 3305-3307. [CrossRef] [PubMed]

3. Shi, X.; Zhu, G.; Qiu, S.; Huang, K.; Yu, J.; Xu, R. Zn $\mathrm{Zn}_{2}\left[(S)-\mathrm{O}_{3} \mathrm{PCH}_{2} \mathrm{NHC}_{4} \mathrm{H}_{7} \mathrm{CO}_{2}\right]_{2}$. A Homochiral 3D Zinc Phosphonate with Helical Channels. Angew. Chem. Int. Ed. 2004, 43, 6482-6485. [CrossRef] [PubMed]

4. Fu, R.-B.; Hu, S.-M.; Wu, X.-T. Two new molecular zinc phosphonates with bright luminescence for sensing UV radiation. CrystEngComm 2013, 15, 8937-8940. [CrossRef]

5. Huang, J.; Bao, S.-S.; Ling, L.-S.; Zhu, H.; Li, Y.-Z.; Pi, L.; Zheng, L.-M. A Racemic Polar Cobalt Phosphonate with Weak Ferromagnetism. Chem. Eur. J. 2012, 18, 10839-10842. [CrossRef] [PubMed]

6. Du, Z.-Y.; Xu, H.-B.; Mao, J.-G. Rational Design of OD, 1D, and 3D Open Frameworks Based on Tetranuclear Lanthanide(III) Sulfonate-Phosphonate Clusters. Inorg. Chem. 2006, 45, 9780-9788. [CrossRef] [PubMed]

7. Zhou, T.-H.; Yi, F.-Y.; Li, P.-X.; Mao, J.-G. Synthesis, Crystal Structures, and Luminescent Properties of Two Series' of New Lanthanide (III) Amino-Carboxylate-Phosphonates. Inorg. Chem. 2010, 49, 905-915. [CrossRef] [PubMed]

8. Zangana, K.H.; Moreno-Pineda, E.; Iñigo, V.-Y.; McInnes, J.L.; Winpenny, R.E.P. Linking $\mathrm{Cr}_{3}$ triangles through phosphonates and lanthanides: Synthetic, structural, magnetic and EPR studies. Dalton Trans. 2014, 43, 13242-13249. [CrossRef] [PubMed]

9. Zhang, Z.H.; Song, Y.; Okamura, T.; Hasegawa, Y.; Sun, W.Y.; Ueyama, N. Syntheses, Structures, Near-Infrared and Visible Luminescence, and Magnetic Properties of Lanthanide-Organic Frameworks with an Imidazole-Containing Flexible Ligand. Inorg. Chem. 2006, 45, 2896-2902. [CrossRef] [PubMed]

10. Shanmugam, M.; Chastanet, G.; Sessoli, R.; Mallah, T.; Wernsdorfer, W.; Winpenny, R.E.P. Minor changes in phosphonate ligands lead to new hexa- and dodeca-nuclear Mn clusters. J. Mater. Chem. 2006, 16, 2576-2578. [CrossRef]

11. Shanmugam, M.; Chastanet, G.; Mallah, T.; Sessoli, R.; Teat, S.J.; Timco, G.A.; Winpenny, R.E.P. Synthesis and Characterization of Mixed-Valent Manganese Phosphonate Cage Complexes. Chem. Eur. J. 2006, 12, 8777-8785. [CrossRef] [PubMed]

12. Zangana, K.H.; Moreno-Pineda, E.; Winpenny, R.E.P. Single molecule magnet behaviour in a $\left\{\mathrm{Dy}_{4} \mathrm{P}_{2}\right\}$ octahedron. Dalton Trans. 2015, 44, 12522-12525. [CrossRef] [PubMed]

13. Zangana, K.H.; Moreno-Pineda, E.; Schnack, J.; Winpenny, R.E.P. Octametallic 4f-phosphonate horseshoes. Dalton Trans. 2013, 42, 14045-14048. [CrossRef] [PubMed]

14. Clearfield, A.; Sharma, C.V.K.; Zhang, B. Crystal Engineered Supramolecular Metal Phosphonates: Crown Ethers and Iminodiacetates. Chem. Mater. 2001, 13, 3099-3112. [CrossRef]

15. Ngo, H.L.; Lin, W. Chiral Crown Ether Pillared Lamellar Lanthanide Phosphonates. J. Am. Chem. Soc. 2002, 124, 14298-14299. [CrossRef] [PubMed]

16. Vojtíšek, P.; Cígler, P.; Kotek, J.; Rudovský, J.; Hermann, P.; Lukeš, I. Crystal Structures of Lanthanide(III) Complexes with Cyclen Derivative Bearing Three Acetate and One Methylphosphonate Pendants. Inorg. Chem. 2005, 44, 5591-5599. [CrossRef] [PubMed]

17. Bligh, S.W.A.; Choi, N.; Geraldes, C.F.G.C.; Knoke, S.; McPartlin, M.; Sanganee, M.J.; Woodroffe, T.M. A novel hexaaza macrocycle with methylenephosphonate pendant arms: A potential useful chelate for biomedical applications. Dalton Trans. 1997, 21, 4119-4126. [CrossRef] 
18. Avecilla, F.; Peters, J.A.; Geraldes, C.F.G.C. X-ray Crystal Structure of a Sodium Salt of $[\text { Gd(DOTP) }]^{5-}$ : Implications for Its Second-Sphere Relaxivity and the ${ }^{23} \mathrm{Na}$ NMR Hyperfine Shift Effects of [Tm(DOTP) $]^{5-}$. Eur. J. Inorg. Chem. 2003, 23, 4179-4186. [CrossRef]

19. Legendziewicz, J.; Gawryszewska, P.; Gałdecka, E.; Galdecki, Z. Novel polynuclear compound of europium with N-phosphonomethylglycine: Spectroscopy and structure. J. Alloys Compd. 1998, 275, 356-360. [CrossRef]

20. Gałdecka, E.; Gałdecki, Z.; Gawryszewska, P.; Legendziewicz, J. Structure of a novel polynuclear europium compound with $N$-phosphonomethylglycine: Heptaaquaperchloratodi- $\mu_{4}-N$-phosphonomethylglycinedieuropium(III) triperchlorate monohydrate, $\left[\mathrm{Eu}_{2}\left(\mathrm{HO}_{3} \mathrm{PCH}_{2} \mathrm{NH}_{2} \mathrm{CH}_{2} \mathrm{CO}_{2}\right)_{2}\left(\mathrm{H}_{2} \mathrm{O}\right)_{7}\left(\mathrm{ClO}_{4}\right)\right] \cdot 3 \mathrm{ClO}_{4} \cdot \mathrm{H}_{2} \mathrm{O}$. New J. Chem. 2000, 24, 387-391. [CrossRef]

21. Tang, S.-F.; Song, J.-L.; Mao, J.-G. Syntheses, Crystal Structures, and Characterizations of a Series of New Layered Lanthanide Carboxylate-Phosphonates. Eur. J. Inorg. Chem. 2006, 2006, 2011-2019. [CrossRef]

22. Yue, Q.; Yang, J.; Li, G.-H.; Li, G.-D.; Chen, J.-S. Homochiral Porous Lanthanide Phosphonates with 1D Triple-Strand Helical Chains: Synthesis, Photoluminescence, and Adsorption Properties. Inorg. Chem. 2006, 45, 4431-4439. [CrossRef] [PubMed]

23. Tang, S.-F.; Song, J.-L.; Li, X.-L.; Mao, J.-G. Luminescent Lanthanide(III) Carboxylate-Phosphonates with Helical Tunnels. Cryst. Growth Des. 2006, 6, 2322-2326. [CrossRef]

24. Głowiak, T.; Huskowska, E.; Legendziewicz, J. Preparation and X-ray crystal structure determination of an octahedral polymeric lutetium compound with ciliatine; $\left\{\mathrm{Lu}\left(\mathrm{PO}_{3} \mathrm{HCH}_{2} \mathrm{CH}_{2} \mathrm{NH}_{3}\right)_{3}\left(\mathrm{ClO}_{4}\right)_{3} \cdot 3 \mathrm{D}_{2} \mathrm{O}\right\}_{n}$. Polyhedron 1991, 10, 175-178. [CrossRef]

25. Groves, J.A.; Wright, P.A.; Lightfoot, P. Two Closely Related Lanthanum Phosphonate Frameworks Formed by Anion-Directed Linking of Inorganic Chains. Inorg. Chem. 2005, 44, 1736-1739. [CrossRef] [PubMed]

26. Comby, S.; Scopelliti, R.; Imbert, D.; Charbonnière, L.; Ziessel, R.; Bünzli, J.C.G. Dual Emission from Luminescent Nonalanthanide Clusters. Inorg. Chem. 2006, 45, 3158-3160. [CrossRef] [PubMed]

27. Cao, D.-K.; Li, Y.-Z.; Song, Y.; Zheng, L.-M. Three-, Two-, and One-Dimensional Metal Phosphonates Based on [Hydroxy(4-pyridyl)methyl]phosphonate: $\mathrm{M}\left\{\left(4-\mathrm{C}_{5} \mathrm{H}_{4} \mathrm{~N}\right) \mathrm{CH}(\mathrm{OH}) \mathrm{PO}_{3}\right\}\left(\mathrm{H}_{2} \mathrm{O}\right)(\mathrm{M}=\mathrm{Ni}, \mathrm{Cd})$ and $\mathrm{Gd}\left\{\left(4-\mathrm{C}_{5} \mathrm{H}_{4} \mathrm{~N}\right) \mathrm{CH}(\mathrm{OH}) \mathrm{P}(\mathrm{OH}) \mathrm{O}_{2}\right\}_{3} \cdot 6 \mathrm{H}_{2} \mathrm{O}$. Inorg. Chem. 2005, 44, 3599-3604. [CrossRef] [PubMed]

28. Gan, X.M.; Bingamin, I.; Rapko, B.M.; Fox, J.; Duesler, E.N.; Paine, R.T. Hydrogen Bonded Framework Structures Constructed from 2-(Pyridyl N-oxide) Methylphosphonic Acid Ligands and Erbium(III). Inorg. Chem. 2004, 43, 2443-2448. [CrossRef] [PubMed]

29. Gan, X.-M.; Rapko, B.M.; Fox, J.; Binyamin, I.; Pailloux, S.; Duesler, E.N.; Paine, R.T. A Three-Dimensional Framework Structure Constructed from 2-(2-Pyridyl-N-oxide) Ethylphosphonic Acid and $\mathrm{Nd}(\mathrm{III})$. Inorg. Chem. 2006, 45, 3741-3745. [CrossRef] [PubMed]

30. Ying, S.-M.; Zeng, X.-R.; Fang, X.-N.; Li, X.-F.; Liu, D.-S. Synthesis, crystal structure and fluorescent characterization of a novel lanthanide tetraphosphonate with a layered structure. Inorg. Chim. Acta 2006, 359, 1589-1593. [CrossRef]

31. Nash, K.L.; Rogers, R.D.; Ferraro, J.; Zhang, J. Lanthanide complexes with 1-hydroxyethane-1,1-diphosphonic acid: Solvent organization and coordination geometry in crystalline and amorphous solids. Inorg. Chem. Acta 1998, 269, 211-223. [CrossRef]

32. Gan, X.-M.; Binyamin, I.; Pailloux, S.; Duesler, E.N.; Paine, R.T. Formation of a layered framework structure based upon 4-methyl-2,6-bis(methylphosphonic acid) phenol. Dalton Trans. 2006, 32, 3912-3917. [CrossRef] [PubMed]

33. Wharmby, M.T.; Miller, S.R.; Groves, J.A.; Margiolaki, I.; Ashbrooka, S.E.; Wright, P.A. Yttrium bisphosphonate STA-13: A racemic phosphonate metal organic framework with permanent microporosity. Dalton Trans. 2010, 39, 6389-6391. [CrossRef] [PubMed]

34. Sakamoto, M.; Manseki, K.; Hisashi, O. d-f Heteronuclear complexes: synthesis, structures and physicochemical aspects. Coord. Chem. Rev. 2001, 221, 379-414. [CrossRef]

35. Du, Z.-Y.; Sun, Y.-H.; Liu, Q.-Y.; Xie, Y.-R.; Wen, H.-R. Octanuclear aluminum(III) and iron(III) phosphonate cages encapsulating two $\mathrm{Na}(\mathrm{I})$ ions. Inorg. Chem. 2009, 48, 7015-7017. [CrossRef] [PubMed]

36. Habib, H.A.; Gil-Hernández, B.; Abu-Shandi, K.; Sanchiz, J.; Janiak, C. Iron, copper and zinc ammonium-1hydroxyalkylidene-diphosphonates with zero-, one- and two-dimensional covalent metal-ligand structures extended into three-dimensional supramolecular networks by charge-assisted hydrogen-bonding. Polyhedron 2010, 29, 2537-2545. [CrossRef] 
37. Li, J.T.; Guo, L.R.; Shen, Y.; Zheng, L.M. LiF-assisted crystallization of zinc 4-carboxyphenylphosphonates with pillared layered structures. CrystEngComm 2009, 11, 1674-1678. [CrossRef]

38. Moreno-Pineda, E.; Tuna, F.; Pritchard, R.G.; Regan, A.C.; Winpenny, R.E.P.; McInnes, E.J.L. Molecular amino-phosphonate cobalt-lanthanide clusters. Chem. Commun. 2013, 49, 3522-3524. [CrossRef] [PubMed]

39. Zhang, Z.-M.; Zangana, K.H.; Kostopoulos, A.K.; Tong, M.-L.; Winpenny, R.E.P. A pseudo-icosahedral cage $\left\{\mathrm{Gd}_{12}\right\}$ based on aminomethylphosphonate. Dalton Trans. 2016, 45, 9041-9044. [CrossRef] [PubMed]

40. Aboshyan, S.L.; Cantuel, M.; Petoud, S.; Hauser, A.; Piguet, C. Optical sensitization and upconversion in discrete polynuclear chromium-lanthanide complexes. Coord. Chem. Rev. 2012, 256, 1644-1663. [CrossRef]

41. Mao, J.-G. Structures and luminescent properties of lanthanide phosphonates. Coord. Chem. Rev. 2007, 251, 1493-1520. [CrossRef]

42. Zheng, Y.-Z.; Moreno-Pineda, E.; Helliwell, M.; Winpenny, R.E.P. Mn(II) -Gd(III) phosphonate cages with a large magnetocaloric effect. Chem. Eur. J. 2012, 18, 4161-4165. [CrossRef] [PubMed]

43. Konar, S.; Clearfield, A. Synthesis and characterization of high nuclearity iron(III) phosphonate molecular clusters. Inorg. Chem. 2008, 47, 5573-5579. [CrossRef] [PubMed]

44. Goura, J.; Bag, P.; Mereacre, V.; Powell, A. K.; Chandrasekhar, V. Molecular iron(III) phosphonates: Synthesis, structure, magnetism, and Mössbauer studies. Inorg. Chem. 2014, 53, 8147-8154. [CrossRef] [PubMed]

45. Patterson, A.R.; Schmitt, W.; Evans, R.C. Lighting Up Two-Dimensional Lanthanide Phosphonates: Tunable Structure-Property Relationships toward Visible and Near-Infrared Emitters. J. Phys. Chem. 2014, 118, 10291-10301. [CrossRef]

46. Song, J.-L.; Lei, C.; Mao, J.-G. Syntheses, Crystal Structures, and Luminescent Properties of Novel Layered Lanthanide Sulfonate-Phosphonates. Inorg. Chem. 2004, 43, 5630-5634. [CrossRef] [PubMed]

47. Song, J.-L.; Mao, J.-G. New Types of Blue, Red or Near IR Luminescent Phosphonate-Decorated Lanthanide Oxalates. Eur. J. Inorg. Chem. 2005, 11, 1417-1424. [CrossRef] [PubMed]

48. Ying, S.-M.; Mao, J.-G. Introducing a Second Ligand: New Route to Luminescent Lanthanide Polyphosphonates. Cryst. Growth Des. 2006, 6, 964-968. [CrossRef]

49. Zheng, Y.-Z.; Evangelisti, M.; Winpenny, R.E.P. Co-Gd phosphonate complexes as magnetic refrigerants. Chem. Sci. 2011, 2, 99-102. [CrossRef]

50. Zheng, Y.-Z.; Evangelisti, M.; Winpenny, R.E.P. Large Magnetocaloric Effect in a Wells-Dawson Type $\left\{\mathrm{Ni}_{6} \mathrm{Gd}_{6} \mathrm{P}_{6}\right\}$ Cage. Angew. Chem. Int. Ed. 2011, 50, 3692-3695. [CrossRef] [PubMed]

51. Zheng, Y.-Z.; Evangelisti, M.; Tuna, F.; Winpenny, R.E.P. Co-Ln Mixed-Metal Phosphonate Grids and Cages as Molecular Magnetic Refrigerants. J. Am. Chem. Soc. 2012, 134, 1057-1065. [CrossRef] [PubMed]

52. Zangana, K.H.; Moreno-Pineda, E.; McInnes, E.J.L.; Schnack, J.; Winpenny, R.E.P. Centred nine-metal rings of lanthanides. Chem. Commun. 2014, 50, 1438-1440. [CrossRef] [PubMed]

53. Coxall, R.A.; Harris, S.G.; Henderson, D.K.; Parsons, S.; Tasker, P.A.; Winpenny, R.E.P. Inter-ligand reactions: In situ formation of new polydentate ligands. Dalton Trans. 2000, 14, 2349-2356. [CrossRef]

54. Moreno-Pineda, E.; Lorusso, G.; Zangana, K.H.; Palacios, E.; Schnack, J.; Evangelisti, M.; Winpenny, R.E.P.; McInnes, E.J.L. Observation of the influence of dipolar and spin frustration effects on the magnetocaloric properties of a trigonal prismatic $\left\{\mathrm{Gd}_{7}\right\}$ molecular nanomagnet. Chem. Sci. 2016, 7, 4891-4895. [CrossRef]

55. Bochkarev, M.N.; Fedorova, E.A.; Radkov, Y.F.; Khorshev, S.Y.; Kalinina, G.S.; Razuvaev, G.A. Carbon dioxide fixaion by lathanide complexes. J. Organomet. Chem. 1983, 258, C29-C33. [CrossRef]

56. Tang, X.-L.; Wang, W.-H.; Dou, W.; Jiang, J.; Liu, W.-S.; Qin, W.-W.; Zhang, G.-L.; Zhang, H.-R.; Yu, K.-B.; Zheng, L.-M. Olive-Shaped Chiral Supramolecules: Simultaneous Self-Assembly of Heptameric Lanthanum Clusters and Carbon Dioxide Fixation. Angew. Chem. Int. Ed. 2009, 48, 3499-3502. [CrossRef] [PubMed]

57. Tian, H.; Zhao, L.; Guo, Y.-N.; Guo, Y.; Tang, J.; Liu, Z. Quadruple- $\mathrm{CO}_{3}{ }^{2-}$ bridged octanuclear dysprosium(III) compound showing single-molecule magnet behavior. Chem. Commun. 2012, 48, 708-710. [CrossRef] [PubMed]

58. Zangana, K.H.; Moreno-Pineda, E.; Winpenny, R.E.P. Tetrametallic lanthanide(III) phosphonate cages: Synthetic, structural and magnetic studies. Dalton Trans. 2014, 43, 17101-17107. [CrossRef] [PubMed]

59. Fomina, I.G.; Kiskin, M.A.; Martynov, A.G.; Aleksandrov, G.G.; Dobrokhotova, Zh.V.; Gorbunova, Y.G.; Shvedenkov, Y.G.; Tsivadze, A.Y.; Novotortsev, V.M. Lanthanum(III), Samarium(III), Europium(III), and Thulium(III) Binuclear Acetates and Pivalates: Synthesis, Structure, Magnetic Properties, and Solid-Phase Thermolysis. Russ. J. Inorg. Chem. 2004, 49, 1463-1474. 
60. Zoan, T.A.; Kuzmina, N.P.; Frolovskaya, S.N.; Rykov, A.N.; Mitrofanova, N.D.; Troyanov, S.I.; Pisarevsky, A.P.; Martynenko, L.I.; Korenev, Y.M. Synthesis, structure and properties of volatile lanthanide pivalates. J. Alloys Compd. 1995, 225, 396-399. [CrossRef]

61. Sheldrick, G.M. Crystal structure refinement with SHELXL. Acta Crystallogr. Sect. C 2015, C17, 3-8. [CrossRef]

62. Dolomanov, O.V.; Bourthis, L.J.; Gildea, R.L.; Howard, J.A.K.; Puschmann, H. OLEX2: A complete structure solution, refinement and analysis program. J. Appl. Cryst. 2009, 42, 339-341. [CrossRef]

63. Sluis, P.V.D.; Spek, A.L. BYPASS: An effective method for the refinement of crystal structures containing disordered solvent regions. Acta Cryst. 1990, A46, 194-201. [CrossRef]

64. Evangelisti, M.; Berchin, E.K. Recipes for enhanced molecular cooling. Dalton Trans. 2010, 39, 4672-4676. [CrossRef] [PubMed]

65. Serre, C.; Stock, N.; Bein, T.; Ferey, G. Synthesis and Characterization of a New Three-Dimensional Lanthanide Carboxyphosphonate: $\mathrm{Ln}_{4}\left(\mathrm{H}_{2} \mathrm{O}\right)_{7}\left[\mathrm{O}_{2} \mathrm{C}-\mathrm{C}_{5} \mathrm{H}_{10} \mathrm{~N}-\mathrm{CH}_{2}-\mathrm{PO}_{3}\right]_{4}\left(\mathrm{H}_{2} \mathrm{O}\right)_{5}$. Inorg. Chem. 2004, 43, 3159-3163. [CrossRef] [PubMed]

(C) 2018 by the author. Licensee MDPI, Basel, Switzerland. This article is an open access article distributed under the terms and conditions of the Creative Commons Attribution (CC BY) license (http://creativecommons.org/licenses/by/4.0/). 